\title{
LAS DIMENSIONES SIMBÓLICAS DEL \\ POEMA "EL MAR EN \\ LA CIUDAD" DE \\ EMILIO ADOLFO \\ WESTPHALEN
}

Juan Antonio Rosado*

\section{El poeta}

Emilio Adolfo Westphalen (Perú, 1911) es claro ejemplo del poeta de creación breve que ha ocupado un lugar significativo en la literatura. De temperamento solitario, él mis- . mo considera que su papel en la poesía peruana "ha sido aleatorio y (...) ha dependido mayormente de las circunstancias". 1

Autor de dos reveladores poemarios con marcada influencia surrealista: ${ }^{2}$ Las insulas extrañas (1933) y Abolición de la muerte (1935), Westphalen publicó luego unos ensayos de lo que se llamaba "poesía social', y que según él, no era arte. Al ser apresado por la policía política, se le decomisó un ejemplar de estos ensayos. Nunca compartió los intereses de las clases poderosas y se le acusó de dos crímenes: "el primero ser poeta, el segundo ser comunista".

* Instituto de Investigaciones Filológicas, UNAM.

${ }^{1}$ Dos soledades, 1974, Lima, Instituto Nacional de Cultura. Si no se indica lo contrario, todas las citas de Westphalen fueron tomadas de este texto.

${ }^{2}$ El Diccionario Oxford de literatura española e hispanoamericana lo califica de 'poeta surrealista', 1984, Barcelona, Crítica. 
JUAN ANTONIO ROSADO

Con el fin de los años treinta, se inicia también el silencio del poeta. A partir de entonces, sólo traducirá o escribirá sobre otros poetas. Editó también dos revistas: Las Moradas (1947-1949) y Amaru (19671971).

Como crítico se propondrá nunca desentrañar el significado último de la poesía, pues él mismo afirma: "Es siempre arriesgado especular acerca de los orígenes de una vocación y los impulsos primeros que llevaron a la creación de un poema o una obra de arte". 3

Su poesía completa se publicó en 1981, con el título de Otra imagen deleznable. De sus poemas, he elegido "El mar en la ciudad" por su extraordinaria carga simbólica y mítica. La aproximación que me propongo consta de tres partes. La primera -dividida en dos incisostratará del poema en su conjunto. En la segunda se analizarán los dos símbolos primordiales: el mar y la ciudad. Por último, se sintetizará este hecho de expresión llamado 'poema' en las conclusiones.

\section{EI poema}

a) El sonido y el concepto

Lo que quizá más impresiona al lector del título del poema es la preposición en: "El mar en la ciudad". Las dos presencias, el mar y la ciudad, no están coordinadas por una conjunción copulativa, sino que una está contenida en la otra: el mar está dentro de la ciudad. Este invasor flexible y dinámico se halla personificado: avista a su presa o diosa, es tímido, amoroso, tierno, invade jardines, repite su canción, devora lo muerto...: mientras que la ciudad es escenario estático, desierto, con estatuas rotas y caidas, con fuentes acalladas y modos campanarios.

${ }^{3}$ Westphalen, "César Moro: las bodas alquímicas entre la realidad y el sueño", Casa del tiempo, mayo de 1989, México, U.A.M., p. 2-6.

${ }^{4}$ En: Antología de la poesía hispanoamericana; selección, prólogo y notas de Juan G. Cobo Borda, 1985, México, F.C.E., p. 79. 
Sin duda, la ciudad es símbolo negativo y estático; el mar, positivo y dinámico.

El poema, dividido en seis cuartetos, posee un total de veinticuatro versos que a su vez pueden separarse en tres partes claramente discernibles por su tono y su contenido. El ritmo y la métrica son variables: hay versos de entre nueve y catorce sílabas. Si bien hay preferencia por los versos largos, la mayoría posee una extensión más o menos pareja, tiende a la homogeneidad. El encabalgamiento es prácticamente inexistente. Dos estrofas interrogantes inician el poema y establecen lo que sería una primera parte. Para no perder de vista el ritmo, se subrayarán las vocales tónicas:

¿Es éste el mar que se arrastra por los campos,

Que rodea los muros y las torres,

Que levanta manos como olas

Para avistar de lejos su presa o su diosa?

¿Es éste el mar que tímida, amorosamente

Se piêrde por callejas y plazuchas,

Que invade jardines y lame pies

Y labios de estatuas rotas, caídas?

Como puede apreciarse, el ritmo es irregular. La vocal tónica que predomina es precisamente la más abierta del castellano, la 'a'. Por su parte, la sonoridad que más destaca es la de la 'r' (mar, arrastra, rodea, muros, torres...). Ligada acaso al rugido de las aguas, contrasta con la suavidad nasal de la 'm' ( $m$ ar, campos, muros, manos, como...). Esta pugna, como veremos, trasciende el plano fonético.

Con versos de diez a catorce sílabas, estas dos estrofas giran alrededor del verbo ser: el poeta se cuestiona por la identidad y por la esencia del mar. El tono retórico de las preguntas es admirativo: "¿Es éste el mar...?" El verbo copulativo y el pronombre demostrativo éste inauguran un tiempo ahistórico, no lineal, con dos largas preguntas que la 
JUAN ANTONIO ROSADO

segunda parte (constituida por la tercera y la cuarta estrofa), responde de modo indirecto; la respuesta implícita es "sí, éste es el mar".

Pero el mar se arrastra, no corre, no camina, se arrastra-verbo que sugiere lentitud, cansancio, vejez- por los campos y llega a la ciudad, donde ya no hay campos, donde una serie de presencias citadinas, estáticas, que contrastan con la dinamicidad del agua en movimiento, se expresan como seres muertos: los muros y las torres son rodeadas por el agua salada y consciente del mar, que no levanta sus olas como si levantara sus manos, sino que levanta manos -entidades fragmentarias- como si fueran olas, acaso las manos de esas estatuas rotas y caídas cuyos labios y pies son lamidos por el mar, con mente tímida y amorosa. Una estatua representa, por lo general, a un ser vivo o que estuvo vivo. Doblemente muerta es una estatua mutilada, fragmentada. Las callejas y plazuchas por donde el mar se pierde, los jardines invadidos por el agua, son también presencias muertas. Lo único vivo es el mar, elemento de la Naturaleza que enfáticamente avista de lejos sụ presa o su diosa, su objeto de agresión (la presa) o de reverencia (la diosa). La pugna es clara. Además, el mar se pierde por callejas. Cada imagen establece un contraste a nivel fonético y conceptual. Pero allí

72. no se detiene el mar, sino que penetra también en lugares ocultos, subterráneos, en sótanos y alcantarillas:

No se oye otro rumor que el borbotón

Del agua deslizándose por sótanos

Y alcantarillas, llevando levemente

En peso hojas, pétalos, insectos.

La vocal 'o' se repite ocho veces en el primer verso, donde también es tónica y, mezclada al constante sonido ' $r$ ', acaso evoca la violencia del agua que arrastra lo fragmentario, lo plural, lo particular, para incluirlo en su esencia absoluta. El único rumor es el del mar, ser vivo que lleva, no plantas enteras, no rosas íntegras, sino sólo fragmentos: hojas y pétalos, así como en la primera estrofa levantaba manos. Aquí también lleva insectos, que por ser llevados están muertos, son despo- 
jos carentes de voluntad y de reacción. El mar en esta estrofa se ha convertido en un borbotón cuyas aguas, que se deslizan por sótanos, pronto se reavivarán. Luego, la cuarta estrofa vuelve a interrogar:

¿Qué bussca el mạr en la ciudad desierta,

Abandonada aun por gatos y perros,

Acalladas todas sus fuentes,

Mudos los tenues campanarios?

Nótese cómo la segunda parte (tercera y cuarta estrofa) es sumamente lenta en comparación con la primera. Incluso el tono de la última interrogación es distinto al de las primeras dos. Cada pregunta abarca una estrofa, pero aquí la admiración ha desaparecido y la aseveración es ya un hecho, aunque la pugna de las imágenes continúa. La cuarta estrofa alude a la ciudad desierta e incluye el mayor juego vocálico (posee 35 vocales y 6 diptongos). La constante ' $r$ ' disminuye y es casi sustituida por la vocal más abierta, la 'a' (busca, mar, ciudad, desiert $a, a$ bandon $a \mathrm{~d} a$, acallad $a \mathrm{~s} . .$.$) , que también juega un importante$ papel como tónica, lo que expresa una mayor fuerza evocativa y sonora.

En esta estrofa se advierte que no hay nada vivo en la ciudad, ni perros ni gatos, ni siquiera las fuentes. Sus campanarios están mudos. Todo es soledad. Antes de la llegada del mar solo había silencio, ahora sólo el borbotón del agua. ¿Pero qué busca el mar?, ¿qué busca? Nuevamente, la respuesta será develada en la tercera parte (las dos últimas estrofas):

La ronda inagotable prosigue,

El mar enarca el lomo y repite

Su canción, emisario de la vída

Devorando todo lo muerto y putrefacto.

El mar, el tierno mar, el mar de los orígenes,

Recomienza el trabajo viejo:

Limpiar los estragos del mundo,

Cubrirlo todo con una rosa dura y viva. 
JUAN ANTONIO ROSADO

"El mar enarca el lomo y repite", pero también el poema agiliza su velocidad, que contrasta con la lentitud de la segunda parte. Aquí también retorna el constante y mágico sonido de la ' $\mathrm{r}$ ' (en palabras como ronda, prosigue, mar, enarca, repite, emisario, devorando, muerto, putrefacto...). Nuevamente la ' $a$ ' es la vocal tónica más constante, aunque al final de cada verso hay una preferencia por la ' $i$ ' (prosigue, repite, vida, orígenes, viejo -como semiconsonante- y viva), lo que da una sonoridad palatal y contrastante. La rima asonante "-igue / -ite" es la única rima clara en el poema. También es interesante notar el comportamiento de la ' $\mathrm{j}$ ' en dos palabras seguidas del segundo verso de la última estrofa: "trabajo viejo", que contrasta con la dureza de la " $r$ '.

Ambas estrofas empiezan con un sujeto: "La ronda inagotable" y "El mar". Este último núcleo se repite tres inagotables veces en el mismo verso, que por ello mismo se vuelve más rápido: "El mar, el tierno mar, el mar de los orígenes": el clímax se aproxima con un énfasis en la presencia principal del poema, El mar devora todo lo muerto y putrefacto, limpia los estragos del mundo. El mar trasciende el mundo y lo muerto con dos verbos transitivos (devora y limpia). Ambos implican la anulación del Otro, el exterminio de elementos externos, pero en este caso, del Otro con signo negativo: la muerte, la putrefacción, los estragos...

En conclusión, la pugna, la fuerte oposición de sonidos y conceptos, logra constituir una dialéctica que se expresa también en el cambio de tono que se produce de la segunda a la tercera estrofa y de la cuarta a la quinta. Este constante diálogo, esta confrontación de imágenes y sonidos no es gratuita, va más allá del mero plano semántico o fonético, roza fuertemente el plano mítico y además expresa una denuncia que puede abrirse no sólo al campo de lo meramente humano como tal, sino también a un nivel social y político. El poema de Westphalen contiene una riqueza de niveles con la que adquiere un sentido profundo que se analizará a continuación. 


\section{b) Denuncia, mito y unión de los opuestos}

La riqueza, la profundidad de este poema no sólo se encuentra en el sentido de los sonidos o de la oposición de sus imágenes y conceptos. El poema propone la sacralización de un elemento de la Naturaleza -La Nature est un temple, dice Baudelaire-, el Mar, cuyas dimensiones míticas lo convierten en el destructor del mal (representado por la ciudad muerta). En el poema es evidente la carencia de un tiempo lineal. Nos enfrentamos a un tiempo mítico, sagrado, en que 'los bosques de símbolos' ven al hombre con 'miradas familiares', para citar a Baudelaire. Pero el texto va todavía más lejos, propone una denuncia social e incluso política, se inscribe dentro de esa tradición occidental que parte de la Modernidad para atacar sus propios efectos, sobre todo la crisis espiritual producida por la Revolución industrial, que ha degenerado en tecnolatría y en la destrucción sistemática de la Naturaleza. El poeta se convierte en el gran sacralizador de lo desacralizado (la Naturaleza): sus símbolos de la vida luchan contra sus símbolos de la muerte. El mismo Westphalen reconoce que

Algo de esa sorda lucha mía contra la muerte tengo la impresión que pudo quedar impregnada en los poemas mismos. No por nada al segundo cuaderno de poemas que publiqué le di por título Abolición de la muerte.

En "El mar en la ciudad", Westphalen impone la abolición de la muerte. Ya se habló de la prosopopeya aplicada a las aguas del mar, pero si la ciudad estuviera también personificada, quizá se expresaría con claridad la lucha épica del cosmos contra el caos. El mar, la inmensidad, el orden, no tiene que luchar contra la ciudad muerta: ella misma se ha aniquilado. El autoaniquilamiento de la civilización es producto de la política destructiva del ser humano y la Naturaleza lo salvará porque, como dice Westphalen, si bien la actividad poética es una necesidad vital, 
No se obtendrá de ella (...) la 'abolición de la muerte', pero sí, quizás, hacer más llevadera la vida. Sería una expresión más de la condición humana, del impulso a no admitir lo real como definitivo e incambiable, a querer superarlo. En la poesía, en la revolución y en el amor veo actuantes los mismos imperativos esenciales: la falta de resignación, la esperanza a pesar de toda previsión razonable contraria.

En el poema, el mar se pierde por callejas 'tímida, amorosamente'; el mar, tierno revolucionario, quiere y propicia una transformación y ello lo asemeja a quienes anhelan el cambio a todo nivel. El mar goza de una mentalidad adversa a la Revolución industrial, pero a la vez pertenece a un poema de la Revolución y del Amor, es decir, de lo dinámico, de la acción, de la actividad contra el anquilosamiento y la putrefacción. El poeta no admite la muerte como definitiva, no se resigna tan fácilmente y se rebela ante ella, por eso asume la forma del tímido mar. Hay una dialéctica entre Ser (el mar) y No ser (la ciudad). Pero eso no es todo: el mito del Eterno retorno, creación y destrucción periódica del cosmos, hace también su aparición. Leamos nuevamente, con cuidado, la quinta estrofa (los subrayados son míos):

La ronda inagotable prosigue.

El mar enarca el lomo y repite

Su canción, emisario de la vida

Devorando todo lo muerto y putrefacto.

El sustantivo 'ronda', el verbo 'repite' marcan el fin y el inicio de un ciclo. Es curioso que el único encabalgamiento claro en el poema se dé entre el segundo y el tercer verso de esta estrofa: 'repite / su canción; emisario de la vida'. El sustantivo 'canción' posee un valor positivo que se enfatiza asociado al sustantivo 'vida' en contraposición con lo 'muerto y putrefacto'. Como en muchas filosofías y religiones orientales, tras la destrucción viene el renacimiento. Así, el mar, en el mito que plantea el poema, 'Recomienza el trabajo viejo': La mer toujours 
recomencée - para citar a Valéry- cubrirá el mundo de vida. Leamos una vez más la última estrofa (los subrayados son míos):

El mar, el tierno mar, el mar de los orígenes,

Recomienza el trabajo viejo:

Limpiar los estragos del mundo,

Cubrirlo todo con una rosa dura y viva.

Una vez más, el mar es adjetivado de modo positivo: 'tierno', pero también es el mar de los orígenes, que vuelve a empezar un viejo trabajo: limpiar el mundo. El mito del Eterno retorno es aun más claro en esta última estrofa que en la quinta. La Rosa dura y viva del último verso -ya en la tercera estrofa se habían anunciado los pétalos- es la Unidad, la unión de esos pétalos, la síntesis de los contrarios ser-noser, vida-muerte, mar-ciudad. La rosa es el vínculo del ser y del no-ser en sí misma, el principio negativo y el positivo, el Tao, el Brahman, lo Absoluto.

Es curioso que el aspecto más general de la rosa sea "el de la manifestación, salida de las aguas primordiales, por encima de las cuales se eleva y se abre". 5 mar del poema es "el mar de los orígenes". La rosa es también "símbolo del amor y más aún del don del amor, del amor puro". 6 Aunque el poema no plantee un mito en sí, no cabe duda de que participa de él. Extraigamos ahora los dos símbolos antitéticos del poema y veamos -sin perder de vista al poema- lo que han significado como elementos culturales.

${ }^{5}$ Jean Chevalier, Alain Gheerbrant, Diccionario de los simbolos, 1991, Barcelona, Herder. Subrayado mío.

${ }^{6}$ Ibid. 
JUAN ANTONIO ROSADO

\title{
III.Los símbolos
}

a) El mar

\author{
Pourquoi le spectacle de la mer est-il \\ infiniment et si éternellement agréable? \\ Parce que la mer offre à la fois l'idée de \\ l'immensité et du mouvement.
}

Mon coeur mis à nu, Baudelaire.

Muchos poetas le han cantado al mar desde a antigüedad más remota. El mar ha simbolizado, entre otras cosas "la dinámica de la vida. Todo sale del mar y todo vuelve a él: lugar de los nacimientos, de las transformaciones y de los renacimientos". ${ }^{7}$ Esto es claramente notorio en Westphalen, cuyo mar también simboliza la vida y todo se reabsorbe lentamente en él. El mar es abundancia, fertilidad, sabiduría, verdad, pero también destrucción: ${ }^{8}$ creación y destrucción a la vez. El mar no sólo es fuente de vida, sino también su fin: regresar al mar es regresar a la madre, pues el símbolo !materno se relaciona con el mar y con la tierra: el agua mantiene la vida y circula por toda la naturaleza "en forma de lluvia, savia, leche, sangre". ${ }^{9} \mathrm{El}$ agua es "fuente de vida, medio de purificación y centro de regeneración". ${ }^{10}$

En Westphalen, las aguas son precisamente destructoras de la muerte y por ello otorgan vida: son las aguas primordiales que retornan para crear un renacimiento. El mar es inmenso y dinámico. Su movimiento

${ }^{7}$ Ibid.

${ }^{8} \mathrm{Cfr}$. Jobes, Gertrude, Dictionary of mythology, folklore and symbols, I, 1962, New York, The Scarecrow Press Inc.

${ }^{9}$ Juan Eduardo Cirlot, Diccionario de símbolos, 1992, Barcelona, Labor. ${ }^{10}$ Chevalier y Gheerbrant, op. cit. 
"EL MAR EN LA CIUDAD"

es eterno y creador. Viajemos ahora a esa muerte de concreto, llamada 'ciudad'.

\section{b) La ciudad}

Es imposible divorciar el fenómeno literario de su contexto social e histórico, por más que esté lleno de vivencias personales o introspecciones. En efecto, por más psicológico o intimista que sea un poeta, sus vivencias no se dan aisladas, sino en una realidad colectiva que experimenta y aprehende. Por ello concuerdo con Elías Canetti cuando afirma que el verdadero escritor "vive entregado a su tiempo", "es el sabueso de su tiempo". "Westphalen, sabueso de su tiempo y de su lugar, sostiene lo mismo al decir que "sería exagerado atenerse a la concepción romántica del poeta como legislador del universo o como transformador de la sociedad. Cada poeta expresa un dilema: el suyo y el de su tiempo". Este dilema está simbolizado en esa pugna poética llamada "El mar en la ciudad", donde la naturaleza vence a la urbe moderna.

En este sentido, se puede alegar que gran parte de la literatura occidental, sobre todo desde el siglo XIX, tiene como base principal la Revolución industrial, los efectos psicológicos y sociales de este fenómeno, sea o no mencionado como tal: la inmigración masiva a las grandes ciudades, la paulatina soledad del hombre urbano, la depauperación de grandes sectores (que ya existía desde las inmigraciones preindustriales), etc. Estos fenómenos se acentúan hasta el paroxismo y en "El mar en la ciudad" llegan a convertir a la ciudad en un lugar desértico, sin vida, despoblado aun de perros, gatos y fuentes. El Romanticismo reaccionará contra la masificación del ser humano y el eco de los críticos de la Modernidad llega a oídos de Westphalen.

Sin embargo, tanto en el poeta peruano como en muchos autores del siglo XX, ya no es el tedio baudelairiano o la masificación en la

${ }^{11}$ La conciencia de las palabras, 1981, México, F.C.E., p. 18. 
urbe lo que producirá su malestar, sino la soledad urbana, la soledad en compañía.

Con el tiempo, la Naturaleza será paulatinamente devorada por la Modernidad y en la literatura las grandes ciudades se llegan a convertir en los escenarios principales. Cabe mencionar que Westphalen será un habitante de la capital peruana hasta ya muy entrado en años:

Durante mucho tiempo mis límites de desplazamiento no pasaron de Ancón, Chosica y Lurín, y no por preferencia propia sino por imposibilidad material para viajes de turismo o estudio. Considero sin embargo, que ese hecho no me excluía de la problemática del Perú entero.

Sin duda la ciudad del poema es Lima. Pero, además de que las ciudades han simbolizado Centros del universo o lugares estables, a pesar de que algunos autores -como Jung- las consideren símbolos maternos, que albergan al hombre, la ciudad del poema es una ciudad moderna y, como dice Gertrude Jobes:

Most moderns regards the city as a place where one is cut off from natura and spiritual life, and writers frequently depict loneliness through aspects of city life. Kafka regarded the city as a place where the individual loses his identity. ${ }^{12}$

Si bien en el poema de Westphalen la ciudad es desierta, la Naturaleza se impone: ha llegado la hora de la renovación, es hora de que el ciclo o la ronda-como dice el poeta- se reinicie. La purificación del agua traerá amor: de ella emergerá la Rosa, pero una rosa 'dura y viva', la rosa de un Edén donde la vida empezará a ser nuevamente llevadera.

${ }^{12}$ Gertrude Jobes, op. cit. 


\section{Conclusiones}

Lo débil siempre vencerá a lo fuerte

Nada hay en el mundo tan débil y flexible como el agua

Pero cuando ataca a lo duro y a lo fuerte demuestra su poder Así lo débil vence a lo fuerte y lo flexible a lo duro.

Estas palabras de Lao Tsé ${ }^{13}$ nos revelan una vez más algo implícito en el poema de Westphalen, que participa de una poética vitalista, donde Eros vence a Tánatos: el agua flexible y débil vence a la ciudad fuerte y dura. Hay un rescate de la dimensión mítica operado en el arte occidental como consecuencia de la crisis espiritual y de la pérdida de valores absolutos. Autores como Albert Béguin proponen que el poeta moderno responde con mitos o con un mito a una serie de preguntas que su misma condición humana ante el universo le plantea. ${ }^{14}$

Sin embargo, el poeta peruano admite que el plano emotivo es el propio del poeta y del artista: "Siempre y en todas las artes será cuestión de la transmisión de una emoción y no de una idea; por ello ofende toda tentativa de introducir tesis y lemas en la obra de arte." Pero en "El mar en la ciudad" hay (desde el título) dos presencias: una activa y otra pasiva, una viva y otra muerta. Esto es claro y no presenta ambigüedades, por lo tanto es factible tener una posición (tesis) frente a la obra de arte. No entraremos en la árida polémica de si el poema de Westphalen es simbolista o surrealista. La emoción que las imágenes produce es incuestionable y esa emoción está vinculada, sin lugar a dudas, a todos los niveles del poema, incluyendo el mítico, pues el mito expresa verdades primordiales de modo simbólico y el símbolo representa una idea de modo sensible: se capta por los sentidos y éstos producen la emoción.

${ }^{13}$ Tao te king, 1982, México, Premiá.

${ }^{14}$ Creación y destino, Ensayos de crítica literaria, 1986, México, F.C.E., vol. I, p. 143. 
JUAN ANTONIO ROSADO

Como ya se había mencionado, Westphalen no propone la creación de un mito, sino simplemente participa o parte de éste. En el plano mítico del poema la dialéctica, la síntesis de los contrarios, juega un papel de primer orden. Esta dialéctica, planteada también en el plano semántico, fonético e incluso socio-político y descubierta por la misma contemplación de la Naturaleza, se encuentra ya de modo implícito y explícito en textos de la más remota antigüedad, como en algunos himnos del Rig Veda sánscrito, en textos del taoísmo y de Heráclito. Consciente o inconscientemente, el hombre de todas las épocas redescubre, aplica y plasma esta sutil observación en sus obras de arte o de la filosofía. El Mar de Westphalen es suave, blando, tierno, amoroso, tímido... Es también, como en el Veda, el origen de la vida. La rosa englobará al mundo, lo apartara de la rigidez y dureza de la ciudad y lo hará retornar a la Edad de oro, donde ya nada estará fragmentado, donde el perfume de la 'rosa dura viva' reinará sobre la muerte en un Paraíso recobrado. 